\title{
Evaluation of the genotoxic and mutagenic potentials of phytotherapic and homeopathic solutions of Euphorbia tirucalli Lineu (Aveloz)
}

\author{
Juliana Patrão de Paiva ${ }^{1,2,3}$, Livia Gonçalves dos Santos Lima ${ }^{1,2,3}$, \\ Camila Monteiro Siqueira², Janine Simas Cardoso ${ }^{3}$, Carla Holandino² , \\ Alvaro da Costa Leitão ${ }^{3}$ \\ ${ }^{1}$ Instituto Hahnemanniano do Brasil (IHB), Rio de Janeiro, Brazil \\ 2 Faculdade de Farmácia, Universidade Federal do Rio de Janeiro (UFRJ), Brazil \\ ${ }^{3}$ Laboratório de Radiobiologia Molecular, UFRJ, Rio de Janeiro, Brazil
}

\begin{abstract}
Introduction: Euphorbia tirucalli Lineu, commonly known as Aveloz, is a very common plant found in tropical regions [1]. The ingestion or contact with its latex causes symptoms such as vomiting and diarrhea, pallor, skin irritation, hepatotoxicity as well as carcinogenesis [2]. Moreover, the Aveloz latex is also responsible for a few important activities against some infectious and neoplastic diseases. Aveloz latex phytochemical composition may vary according to seasonal aspects and geographic location [3], and it is used either orally or topically in traditional medicine. Popularly known as an antitumoral agent (breast, prostate, lung, kidney), it is used not only in Brazil, but in several other countries. According to the literature, the latex could have a dual behaviour, activating or inhibiting tumoral events [3-6]. However, there are few reports discussing these mechanisms. Besides, the mutagenic and genotoxic potentials of phytochemical and homeopathic Aveloz have not yet been described. Several experimental methods have been used to evaluate the mutagenic and genotoxic effects, such as Inductest, the Ames test and the chromotest. Objective: This study aims to evaluate the genotoxic and mutagenic potentials of Aveloz latex and Aveloz phytotherapic and homeopathic solutions. Methodology: In this study, Aveloz 5 and 30cH are prepared according to Brazilian Homeopathic Pharmacopoeia [7], from Aveloz latex collected in the Center for Natural Products Research (NPPN) at the Universidade Federal do Rio de Janeiro [8]. The Aveloz phytochemical solution was prepared following the doses used in folk medicine: 2 drops diluted in $250 \mathrm{ml}$ of water and 2 drops diluted in $25 \mathrm{ml}$ of water. All test solutions were submitted to the following methodologies: (a) Inductest: assesses the ability of physical or chemical agents to promote lysogenic induction as a response to DNA damage in lysogenic bacteria; (b) The Ames test: uses indicator strains of Salmonella typhimurium, which are sensitive to substances that can induce different types of mutation; (c) Chromotest: evaluates the genotoxicity of chemicals through the induction of the bacterial SOS system. Results: In the Inductest there was no decrease in bacterial survival fraction and no increase in lysogenic cycle. As measured by The Ames test and the chromotest no mutagenic or genotoxic potentials were detected. Discussion: The homeopathic and the phytochemical Aveloz solutions were unable to produce lysogenic induction or mutagenesis in bacterial cells and they were also unable to produce genotoxic effects, as measured by chromotest. Conclusion: Our results showed that no mutagenic or genotoxic damages were induced by all Aveloz preparations studied, thus we are led to believe that patients using Aveloz as a complementary therapy present no side effects in relation to mutagenesis and genotoxicity.
\end{abstract}


Key words: Aveloz, homeopathy, genotoxicity, mutagenesis, phytotherapy.

\section{References:}

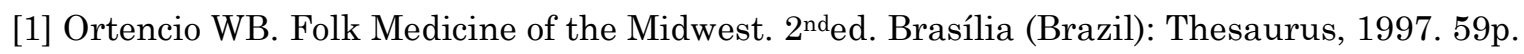

[2] Varricchio MCBN, Pereira C, Sales F, Gomes T, Daudt E, Aquino CL, Barbosa GM, Gomes N, Pyrrho AS, Hobaica PEM, Branco MC, Kuster R, Holandino C. Chronic toxicological effects of high diluted solutions of Aveloz (Euphorbia tirucalli L.) on healthy mice: a preliminary study. Int J High Dilution Res [online]. 2008 [cited $2010 \quad$ Mar 15]; 7(25): 174-178. Available from: http://www.feg.unesp.br/ ojs/index.php/ijhdr/article/view/308/371

[3] Furstenberger G, Hecker E. On the active principles of the Euphorbiaceae, XII. Highly unsaturated irritant diterpene esters from Euphorbia tirucalli originating from Madagascar. Journal of Natural Products. 1986; 49: 386-397.

[4] Sugiura M, Imai S, Sakurada K, Myiazaki T, Osato T. Cryptic dysfunction of cellular immunity in asymptomatic human immunodeficiency virus (HIV) carriers and its actualization by an environmental immunosuppressive factor. 1994; 8: 1019-1022.

[5] Betancur-Galvis LA, Morales GE, Forero JE, Roldan J. Cytotoxic and antiviral activities of colombian medicinal plant extracts of the Euphorbia genus. Memórias do Instituto Oswaldo Cruz. 2002; 97 (04): 541-546.

[6] Bosch CA. Is endemic Burkitt's lymphoma an alliance between three infections and a tumour promoter? The Lancet Oncology. 2004; 5: 738-746.

[7] Brazilian Homeopathic Pharmacopoeia, 2nd ed. SP: Atheneu, 1997.

[8] Varricchio, M.C.B.N. Integrated Studies: Biotechnology, Toxicology, Special metabolites and antitumor activity of Euphorbia tirucalli L. PhD Thesis (Plant Biotechnology Program). Institute of Biophysics Carlos Chagas Filho, Federal University of Rio de Janeiro, 2008.

\section{(c) EY-NC-ND Licensed to GIRI}

Support: IHB, UFRJ, IBCCF, FAPERJ, CNPq, FUJB.

Conflict of interest: authors declare there is no conflict of interest

Correspondence author: Juliana Patrão de Paiva, jupaiva_rj@hotmail.com

How to cite this article: Paiva JP, Lima LGS, Siqueira CM, Cardoso JS, Holandino C, Leitão AC. Evaluation of the genotoxic and mutagenic potentials of phytotherapic and homeopathic solutions of Euphorbia tirucalli Lineu (Aveloz). Int J High Dilution Res [online]. 2011 [cited YYYY Month dd]; 10(35): 71-72. Proceedings of the XXIV GIRI Symposium; 2010 Nov 05; Monte Carlo (Monaco). GIRI; 2010. [cited YYYY Month dd]; Available from: http://www.feg.unesp.br/ ojs/index.php/ijhdr/article/view/446/466 